\title{
Singapore 'A Land Imagined': Rising Seas, Land Reclamation and the Tropical Film-Noir City
}

\author{
Anita Lundberg \\ iD http://orcid.org/0000-0002-0271-4715 \\ James Cook University, Australia \\ Jasmin Thamima Peer \\ James Cook University, Australia
}

\begin{abstract}
Sea level rise due to climate change is predicted to be higher in the Tropics. As a low-lying, highly urbanised island near the equator, Singapore is taking an active response to this problem, including through large land reclamation projects. Incorporating both environmental and aesthetic elements, these projects also serve to bolster Singapore's reputation as a shining example of a global city, a leading arts centre in Southeast Asia, and an economic hub to the world. This paper draws attention to urban development through an ethnographic reading of Yeo Siew Hua's film $A$ Land Imagined. A Singaporean tropical-noir mystery thriller, the film follows the rhizomatic path of a police investigator and his partner as they attempt to solve the disappearance of two foreign labourers. Interwoven within the film is a critique of Singapore's treatment of migrant workers as it constructs the imaginary of the 'Singapore Dream'.
\end{abstract}

Keywords: Singapore city, film ethnography, land reclamation, migrant labour, rising seas, climate change, tropical imaginary, rhizomatics

eTropic: electronic journal of studies in the tropics publishes new research from arts, humanities, social sciences and allied fields on the variety and interrelatedness of nature, culture, and society in the tropics. Published by James Cook University, a leading research institution on critical issues facing the worlds' Tropics. Free open access, Scopus Listed, Scimago Q2. Indexed in: Google Scholar, DOAJ, Crossref, Ulrich's, SHERPA/RoMEO, Pandora. ISSN 1448-2940. Creative Commons CC BY 4.0 free to download, save and reproduce. To cite, include: Author(s), Title, eTropic, volume, issue, year, pages and DOI: http://dx.doi.org/10.25120/etropic.19.2.2020.3739 
eTropic 19.2 (2020) Special Issue: Sustainable Tropical Urbanism

\section{Setting the scene}

$66 \begin{aligned} & \text { s a small, low-lying city-state with one of the world's most open } \\ & \text { economies, Singapore is particularly vulnerable to the impacts of } \\ & \text { climate change" (MFA). This statement from the Ministry of Foreign }\end{aligned}$ Affairs Singapore is an introduction to the government's Climate Action Plan. Environmental impact assessments on the effects of sea level rise, particularly in the Tropics, indicate that rising sea levels pose the most immediate threat to Singapore. Protecting the coastline is one of the nation-state's priorities in dealing with the effects of climate change. Citing the government manual A ClimateResilient Singapore, For a Sustainable Future ${ }^{1}$ the Ministry of Foreign Affairs' website summarises the city-state's plans to adapt to the impacts of climate change through coastal protection and infrastructure, including extensive land reclamation projects.

The Climate Action Plan was addressed in the Prime Minister's National Day Rally speech of August 2019, where he stated the importance of "protecting ourselves from climate change, and renewing our city for the next century" (Lee, 2019). ${ }^{2}$ The threat of coastal inundation posed by rising sea levels was specifically articulated in this section of PM Lee Hsien Loong's speech. The Prime Minister's emphasis on the Climate Action Plan and protection from climate change in association with a vision of the city for the future is simultaneously an economic consideration; it forms part of the 'Singapore Dream'. With its strong ties to the pursuit of economic growth, the Singapore Dream is exceedingly material. It is also cultural, summarised by the notion of 'Asian Values' which focus on pragmatism in order to maintain a stable society that is able to progress economically (Barr, 2000; Patapan, 2013; Tan, 2012).

In turn, Singapore's constant construction - including a long history of land reclamation projects - is associated with boosting the economy, and serves to bolster the Singapore Dream (Glaser et al., 1991, pp. 366-368). The Climate Action Plan working parties comprising government departments, scientists, city planners and engineers are thus recognised as agents in constructing a resilient and futuristic city and continuing the Singapore Dream. However, what remains hidden within this vision are the migrant construction labourers. The island city of 5.70 million inhabitants ${ }^{3}$ relies heavily on its $1,427,500$ foreign workers, of whom 293,300 are construction labourers. ${ }^{4}$ Construction workers are recruited from the

\footnotetext{
${ }^{1}$ Ministry of the Environment and Water Resources; Ministry of National Development (2016).

${ }^{2}$ PM Lee delivered his speech in Malay, Chinese and English. He addressed the Climate Action Plan in English.

3 Department of Statistics Singapore, statistics for end of June 2019.

${ }^{4}$ Ministry of Manpower, statistics for December 2019. Foreign workforce numbers.
} 
eTropic 19.2 (2020) Special Issue: Sustainable Tropical Urbanism

regions of Southeast, South, and East Asia. ${ }^{5}$ Known to receive meagre salaries, to work for long hours with few days off, and to live in crowded dormitories, these labourers have been crucial in the building of Singapore and will play an integral part in the construction of the city of the future. Yet, they remain marginalised from Singapore society (Chin, 2019).

The film, A Land Imagined (Yeo, 2018), makes visible these hidden aspects of the construction of Singapore - the landscapes of reclamation and the conditions of foreign workers who labour to create the city. Written and directed by Yeo Siew Hua, this Singaporean tropical-noir mystery thriller, filmed during the monsoon, creates a certain "wet-noir look" (A Land Imagined Press Kit, 2018). Scripted in English, Mandarin and Bengali, the film follows a police detective and his officer partner as they attempt to solve the disappearance of two foreign construction workers, one from China and one from Bangladesh. Interwoven within the film's cinematic landscapes of reclamation and construction sites is a critique of Singapore's handling and treatment of foreign workers which reveals the socio-ethical costs of the Singapore Dream. The film received international critical acclaim.

This paper analyses the Singapore Dream through the lens of $A$ Land Imagined. It draws from anthropology and cultural geography approaches to cinematic studies in which films are examined as historically situated cultural artefacts. Such studies demonstrate how films "relate to and express sociocultural nuances, critique or reveal hegemonic apparatuses, and suppress or express the narratives of the socially marginalised" (Peer, 2019, p. 2; Gray, 2010; Liew \& Teo, 2017). The anthropology of cinema envisions film as a cultural product to be studied ethnographically, gleaning insights about a place and social concerns through their portrayal in film. This cultural method recognises the interrelation between the context and content of film (Gray, 2010). In human geography, film is analysed as a specific cultural space. In the paper 'Screening Singapore' the authors note the "mutually constitutive relationship between the context of intense economic and urban development and the composition/content of the film images produced" (Law et al., 2011, p. 2). Drawing on earlier work by Clarke (1997), and Shiel and Fitzmaurice (2001), on the 'cinematic city', Law et al. explain that in this interdisciplinary analysis "the cinematic landscape is broadly conceived in social/cultural and material terms and film itself is conceived as text, cultural product, and commodity" (2011, p. 2). Thus scholars are able to "fold textual approaches with more material analyses that consider local and global economies, labour markets... and connections to urban land development" (Law et al., 2011, p. 2).

\footnotetext{
${ }^{5}$ Ministry of Manpower - Foreign Construction Workers - Source Countries or Regions https://www.mom.gov.sg/passes-and-permits/work-permit-for-foreign-worker/sector-specific-rules/constructionsector-requirements
} 
eTropic 19.2 (2020) Special Issue: Sustainable Tropical Urbanism

In the context of the film $A$ Land Imagined, these material analyses of local and global economies, labour markets and urban development, can be extended to considerations of climate change, rising sea levels in the Tropics, and action plans for the future city of Singapore through land reclamation projects. A Land Imagined reveals the socio-ethical implications of the Singapore Dream on the lives of foreign construction workers - issues that remain embedded in Singapore's Dream for a future climate change resilient city. ${ }^{6}$

\section{Yeo Siew Hua's A Land Imagined}

A Land Imagined opens with a "deep focus static shot" inside a massive warehouse filled with mammoth construction machinery, before cutting to an outdoor scene of towering cranes that escape the camera frame - thus trapping the viewer within a "claustrophobic" mise en scène (Sim 2020, p.32). ${ }^{7}$ Later shots establish a skyline of port infrastructure, container ships, oil refineries - and the monstrous stillness of mountains of sand. The voice of the protagonist Detective Lok is heard commenting to his police partner that the land on which they stand did not exist 30 years ago (Sim, 2020, p. 37; Peer, 2019, p. 37). They are on a land reclamation site. This is Singapore; but unrecognisable to most cinema viewers.

Lok, a middle-aged Chinese-Singaporean detective and his police partner enter a rundown site office fitted out with filing cabinets and computers left over from the past century. It is obvious that this company operates on the cheap; a sub-contractor. Speaking mainly in Mandarin, Lok gets the staff to take him to the construction worker's quarters where he encounters 'cramped living conditions: nine to twelve people per small room; sitting and sleeping on bare metal bunk beds; no privacy, comfort, or cleanliness. Appalled, Lok questions how people can live like this' (Peer, 2019 , p. 38). Resting on bunk beds thinly lined with cardboard are two Chinese nationals. He asks them about Wang Bi Chen, the missing foreign worker under investigation. For a bribe they divulge that Wang has not been seen for days - and further reveal that he broke his arm in a workplace accident and has since been taking it easy driving the company bus. The detective and his police partner wander through dormitories resembling prison cells until they come across a group of Bangladeshi migrant workers drumming and dancing in a circle, singing in Bengali (Peer, 2019, p. 38).

\footnotetext{
${ }^{6}$ Films are also revealingly analysed within their national contexts. For a recent contribution to the extensive research on Singaporean film see Lim (2018) Celluloid Singapore: Cinema, Performance and the National. 7 Jiaying Sim's (2020) thick description of the opening sequence of the film is particularly evocative of the affectivity of visuals and music. We have tried to give a sense of that description here.
} 
eTropic 19.2 (2020) Special Issue: Sustainable Tropical Urbanism

As the investigation continues, the Detective and his police partner, connect Wang's disappearance with that of Ajit, a Bangladeshi worker from the same dormitory. In the ongoing investigation, now to find both Wang and Ajit, Detective Lok uncovers the inhumane practices associated with migrant employment in Singapore - insanitary living conditions, the removal of workers' passports, and the withholding of pay. He also learns of Wang's insomnia brought on by the crowded living quarters, which forced him to a late night cybercafé managed by Mindy, an undocumented Chinese woman with short-cropped hair, tattoos and piercings (Peer, 2019, p.38).

The investigators discover that Wang and Ajit had became friends after Wang's accident. The investigation furthermore reveals that the disappearance of Ajit corresponds to a failed attempt to steal back both his own, and Wang's, passports, after which Wang becomes obsessed with Ajit's disappearance, thus exacerbating his insomnia and spiralling his nocturnal escapes to the neon-lit cybercafé. Wang spends sleepless nights playing virtual shooter games, talking online about Ajit's disappearance, and getting trolled. Wang unearths numerous discrepancies regarding his friend's disappearance; including the foreman claiming that Ajit had been sent back to Bangladesh, whereas his passport was still locked in the safe (Peer, 2019, p.38).

As Detective Lok uncovers details about Wang, their subjectivities begin to morph, flicking between Lok's timeline and his imagination of what happened to Wang. Obsessed with tracking down Wang's troll, Lok increasing frequents the cybercafé. As he interacts online through Wang's account, he is ominously forewarned that his police partner will die in the café - which comes to pass during a neon-lit shootout (Peer, 2019, pp. 38-39).

At the beginning of the film, the Chinese migrant worker Wang appeared as the spectre that Lok was trying to bring to light; but as the film deepens, Lok seems to be Wang's 'dream-self' - the ghost-detective that Wang is imagining in the hope "that someone cares about his plight in a Singapore where he goes unseen" (Peer, 2019, p. 39). The film becomes increasingly complex as the main protagonists fade into each other and narrative time folds upon itself. One reviewer notes that this "elliptical narrative, coupled with the explicitly noir passages - marked by stylized and shadowy cinematography - that follow Lok and Wang around a hazy and languid cityscape, give the impression that $A$ Land Imagined exists in a kind of dream state" (Greene, 2019, para. 5).

In turn, the non-linearity of this dream atmosphere resonates with phenomena surrounding subjectivity where characters may be interdependent, interrelated or fluid. It invites hybrid cinematic genres where neo-noir detective thriller may interweave social realism, disturbing distinctions between documentary and fiction. It also conveys 
eTropic 19.2 (2020) Special Issue: Sustainable Tropical Urbanism

shifting identities - an image that has neither beginning nor end, but is always milieu; in-between, spreading and overspilling (Deleuze \& Guattari, 1987, p. 21).

This sense of milieu is evoked in a scene between Wang and the cybercafé manager Mindy. Sitting on a local beach after a late-night swim Mindy remarks that the sand is imported from around the region, "allowing her to visit many Southeast Asian countries, even though she cannot leave Singapore" (Peer, 2019, p. 39). As the film review for Slant notes: "this idea of the island nation as not having a set identity is one that's cannily rhymed to the film's structure" (Greene, 2019, para. 4). The land comprised of shifting sands from surrounding countries; the nation-state forever constructing its identity-Dream; built by the labour of interchangeable flows of migrants chained to precarious contracts as documented ID, but without identity.

In a final scene, Detective Lok is led by the site manager to a green corrugated iron shed where he meets Ajit. Self-censoring, Ajit recites the well worn cliché regarding 'how well he is paid in Singapore compared to neighbouring countries' and that he is happy. When questioned about Wang's disappearance, Ajit remains silent; troubled, he looks to the foreman (Peer, 2019, p. 39).

Filled with construction sites, neon lights, and nightscapes of a Singapore that appears desolate and alien, this non-linear story with mixed subjectivities and lack of closure gives voice to the unseen migrant labourers and landscapes of a Singapore that is being rapidly built by people who can only temporarily live at the margins of a land that they can never inhabit (Peer, 2019, p. 39). The film A Land Imagined critiques the socioeconomic consequences of the Singapore Dream and alerts the audience to the ethical questions the city faces regarding its very foundations - its land and infrastructure.

\section{Singapore: A Land Imagined}

Land and its infrastructure are not mere background to this film, this is the territory from which the film arises. The writer/director Yeo, explains:

For me, architecture and cinema are intimately connected. Structures shape our thoughts and memories. A Land Imagined is a landscape film. Its narrative is fairly simple-a policeman investigates the disappearance of a worker-but its landscape complicates matters. The characters in the film are but figures in a landscape, and the landscape itself is a character (Yeo quoted in Voelcker, 2018, n.p). 
eTropic 19.2 (2020) Special Issue: Sustainable Tropical Urbanism

Indeed, Yeo's initial entry into this film began with the land itself. During a period of three years he undertook research into land reclamation and construction projects; and their concomitant migrant labour. What started out as academic archival research later became more "experiential and immersive" - for over a year he undertook daily visits to the marginal lands of construction sites and labourer dormitories, talking with workers. "I went to these areas to get a sense of them, and wrote early scenes based on what I saw and felt during each visit" (Yeo quoted in Voelcker, 2018, n.p).

A Land Imagined entwines landscapes with notions of imaginaries. In the director's statement for the Locarno Festival Concorso internazionale, Yeo invokes the ideological mythos of the Singapore Dream in relation to land reclamation, construction sites, and migrant labour - positioning each within a field of social imaginaries:

Singapore has garnered itself a reputation as a modern economic miracle, turning itself from a fishing village to a thriving modern economy over the short period of only a few decades. Such a feat is possible due to its ability to systematically engineer a land designed through land reclamation and endless construction projects... a land as though imagined up by some geometrical mind.

Even the people on this imaginary land are at the same time equally imagined. As a country of immigrants, its demography is wholly dependent on migration policies and economic considerations. New migrants are brought into the fold to reinvigorate the imagination of this economic miracle - a success story that is built upon the backs of low wage migrant labourers from the region who are hired to build a nation they can never become a part of.

These indentured workers live in the outskirts of the restless city; existing in the blind spot of larger society; their exploitation remains unseen. They are the invisible and imaginary - they are the sleepless, the dreamless (A Land Imagined Press Kit, 2018, n.p.).

\section{Social Imaginaries}

Yeo's evocation of landscapes and imaginaries alerts us to the work of the anthropologist of globalisation, Arjun Appadurai, who contends that the "global cultural economy" forms a matrix of "imaginary landscapes". In turn, these shared conceptions 
eTropic 19.2 (2020) Special Issue: Sustainable Tropical Urbanism

of the world - social imaginaries - produce tangible and intangible effects (Appadurai, 1996, pp.27, 31; Geerlings \& Lundberg, 2018, p.230).

As the anthropologist observes:

The image, the imagined, the imaginary - these are all terms that direct us to something critical and new in global cultural processes: the imagination as a social practice. No longer mere fantasy...the imagination has become an organized field of social practices...itself a social fact, and is the key component of the new global order (Appadurai, 1996, p. 31).

Here Appadurai poses a view of globalisation through the social imaginary, which he theorizes, is composed of five landscapes of global cultural flows: ethnoscapes, mediascapes, technoscapes, financescapes and ideoscapes. Each of these 'scapes' is perspectival, constructed by social actors as "imagined worlds" (1996, p. 33).

Ethnoscapes refer to the multi-directional movements of people across cultures and borders, including foreign workers. Mediascapes comprise varied and diffuse repertoires of images, which blur fact and fiction in the creation of narratives. Technoscapes arise from the scope and movement of mechanical and informational technologies across national boundaries. Financescapes refer to the rapid flows of trade and capital around the world, which are intensified by neoliberalism. Ideoscapes are political landscapes of symbols and ideologies used by states to promote a national vision.

As an inherent aspect of globalisation, these cultural flows are deterritorialized. Appadurai notes as an example how migrant workers are deterritorialized from their home countries into the lowest labour sectors of wealthy nations (1996, p.37; Geerlings \& Lundberg, 2018, p.231). However, a more fine-grained analysis of deterritorialization was put forward by Gilles Deleuze and Félix Guattari as an aspect of their ecophilosophy of rhizomatics. The root system of rhizomatic plants - such as turmeric and ginger - spread horizontally with nodes connecting lines in all directions. Using this 'image of thought', rhizomatic theory allows for multiplicious, nonhierarchical entry and exit points in the analysis and presentation of ideas; it cultivates diversity of content, where any node of the rhizome can connect to any other; it promotes new ideas, where a node of the rhizome, broken off and transplanted, will give rise to new growth (Deleuze \& Guattari, 1987, p. 21; Lundberg, 2016, pp.108111; Geerlings \& Lundberg, 2018, pp. 231). Deleuze and Guattari argue that deterritorialization (like rhizomatics) is a process of intrinsic, continuous, transformation that also holds the potential to re-create, reterritorialize. What these 
eTropic 19.2 (2020) Special Issue: Sustainable Tropical Urbanism

theorists alert us to is that cities, states, society are not things or entities, and are better understood as potentialities (Geerlings \& Lundberg, 2018, pp. 231-232).

Appadurai contends that globalisation is a 'a complex, overlapping, and disjunctive' system (1996, p. 32). It is non-linear and characterised by ruptures between the different 'scapes' and their varied trajectories. As a result, 'scapes' destabilise one another. This is the case with $A$ Land Imagined: the film as mediascape destabilizes the dominant ideoscape of the Singapore Dream through images and narratives of land reclamation and construction, and reveals the ethnoscape of migrant workers; their lives, labours and disappearance. Thus, the film deterritorializes and reterritorializes land reclamation discourses.

\section{Global City}

The ideology of the Singapore Dream has been cemented within the construction of Singapore as a global city - an important node in the global cultural economy. The phenomenon of the global city was first analysed by Saskia Sassen in 1991 (2002). ${ }^{8}$ Subsequent academic discussions continue to critically analyse the global city (Ong, 2011, p. 6); while a plethora of global city indexes offer "an endless list of rankings and sophistic prestige" (Bullock, 2018, p. 26) regarding what constitutes a global city - all involve global interconnections and flows. Following from our discussion of globalisation and social imaginaries, here we cluster global city criteria under similar 'scapes' of: politics, finance, technology, media/culture, and people.

Politics includes the global city's involvement in regional and world affairs, for instance regional leadership and engagement in global policies such as the UN Sustainable Development Goals. Finance involves the city as a trade hub for flows of goods and money, and requires headquarters for multinational corporations. Technology incorporates both mechanical and informational networks, including the city as a hub for international air and sea links with world renowned (air)port facilities, and efficient city-wide connectivity. Media and culture necessitate that the global city possesses world class cultural institutions such as museums, galleries, theatres, heritage sites and gardens, which contribute to a lively international cultural scene through art and film festivals (Chaudhury \& Lundberg, 2018). Furthermore, the city must be a node of global media networks, which play a role in representing the city through narratives and images, including through film. A global city must have diverse peoples, a multicultural population and international workforce, and the city must cater to this

\footnotetext{
${ }^{8}$ Interestingly, Singapore as an island-state in a world of potential trade was self-described by the Minister of Foreign Affairs as a "global city" in a 1972 speech, two decades before the concept entered urban theory (Tan, 2012, p.70; Chua, 2011, p.31).
} 
eTropic 19.2 (2020) Special Issue: Sustainable Tropical Urbanism

cosmopolitan society by providing a safe environment, health facilities, entertainment, and globally-ranked research and educational facilities.

Importantly, a global city must present an internationally recognisable cityscape. Singapore embraced this global urban development outlook in the 2000s with the implementation of a master plan to design and engineer the Singapore image. Furthermore, this image incorporated a pragmatic push towards Singapore consolidating itself as a 'global city of the arts'; a city able to attract multi-million dollar creative and knowledge-based industries (Chaudhury \& Lundberg, 2018, p.111). The outcome is the Marina Bay area, where the waters reflect the surrounding architectural spectacle: the central business district with its skyscrapers displaying corporate logos; the iconic Marina Bay Sands, with its art deco ship-like capstone and infinity pool; the ArtScience Museum rising like a lotus hand from a pond; the Helix Bridge, with its double DNA spirals; the Esplanade - Theatres on the Bay, colloquially dubbed the durian; and Gardens by the Bay, with its grove of Supertrees. In turn, this skyline is a visual beacon to attract further international cultural and capital flows to the city.

\section{Land Exposed}

Notably, what lies hidden beneath this dream cityscape is reclaimed land. This unseen aspect of the city-state, the land itself, is exposed in A Land Imagined.

The film is the culmination of my thoughts on the island-state where I live and work. This is a land that has been "reclaiming" itself since before its inception as a nation and has never stopped filling its seas with sand to expand its land mass. Much of this sand is imported from other countries, like the labour that is brought here to help reshape this land (Yeo, interview with Cheah, A Land Imagined Press Kit, 2018, n.p.).

The film critiques the human consequences of the Singapore Dream by bringing the very foundations of this global city under ethical investigation - the land, the state, and society. These concerns are unearthed through stark visuals of land reclamation and construction sites, an exposé of migrant worker conditions, and the film's concluding neo-noir twist that gives voice to the ghostly spectre of a migrant labourer (Peer, 2019, p. 39-40).

The film brings the land of Singapore under investigation with opening footage of work sites filled with construction machinery and mountains of sand. The choice of these sites is especially poignant as they bring the unseen building and expansion of the nation into focus. These spaces, rarely filmed, remain at the periphery of the social 
eTropic 19.2 (2020) Special Issue: Sustainable Tropical Urbanism

imaginary of the global city. In A Land Imagined, cinematography in these landscapes uses documentary qualities combining amplified poetic elements with cinema verité to show the physicality of construction. As the director Yeo explains:

Set mostly in the industrial west of Singapore, the film explores a landscape that is not the familiar glitzy skyscraper, but the ugly machinery tucked away at the fringe that runs it. When I first visited the construction work site for my research, I remember my body was thrown into shock from the harsh conditions faced everyday by the workers. The merciless sand blowing incessantly at one's face and the brutal cacophony of noise generated from the machines was utterly unbearable. Much of the visual and audio design of the film is based on my wanting to capture this reality and present it on screen. I don't believe such working conditions are something that one can ever get used to, so it was a conscious decision to heighten the experience of the work site to a certain intensity and not just a humdrum routine (Yeo interview Cheah Press Kit ).

These alien landscapes, unrecognisable to the majority of local and international cinema viewers, offer a critique of the Singapore Dream as something conceived and created for Singaporeans, yet birthed by the labour of migrant workers. Land reclamation sites exist physically at the edge of the city-state in a liminal realm betwixt land and sea. And, like reclaimed land, the migrant labourers who construct this dream city exist at the margins (Peer, 2019, p. 40).

The ethics of the Singapore Dream is further questioned through the film's exposé into the conditions of migrant construction workers. Migrant labour is impacted by structural practices incorporated within globalisation with its concomitant economics of neoliberalism which offer malleable techniques of governing, including through state deregulation - an assemblage which serves to make labour mobile, flexible, cheap and dispensable (Chin, 2019, p. 529-530). As Yeo elucidates in his director's statement for the Locarna Film Festival, this is the human cost of the Singapore imaginary:

With no recourse for grievances, the migrant workers live in precarity. The constant fear of repatriation, with debt incurred from training and agency fees even before they start to work and earn, continue to entrap them in their wretched situation (A Land Imagined Press Kit, 2018, n.p.). 
eTropic 19.2 (2020) Special Issue: Sustainable Tropical Urbanism

In 'Precarious Work and its Complicit Network', Chuanfei Chin (2019), analyses the cultural landscape of migrant workers' vulnerability in Singapore. His article examines how precarious work involves the role of the state through labour laws and policies entailing ministries, work visas, low wages and short contracts; international affiliations including training centres and recruitment agencies; and business practices incorporating multiple levels of subcontracting. As a consequence of such employment conditions workers are rendered "economically insecure and socially marginalized" (Chin, 2019, p.529).

Legally, foreign workers must abide by the labour laws set out in Singapore's Employment of Foreign Manpower Act which covers any person issued a work pass (visa) by the Ministry of Manpower (Ministry of Manpower, 2019). Most migrant construction labourers are issued the 2-year Work Permit, tied to an employer's fixedterm contract. Part IV of the Employment Act specifically prescribes conditions of service as they pertain to manual labourers (Ministry of Manpower, 2019). ${ }^{9}$ As Chin argues, work permits bind migrant labourers to specified employment sectors and employers, with no recourse to permanent residency or family life. Thus individual workers exist in a circumstance of temporary status; nevertheless, "collectively, these migrants are now a permanent part of the workforce" (2019, p. 531).

Chin analyses how migrant workers are recruited overseas by foreign agents within approved source countries around Asia. To certify the skills of workers, the Singapore Building and Construction Authority appoints overseas testing centres. The expensive recruitment, training and testing process has to be paid upfront, forcing many migrant labourers to borrow money. Arriving in Singapore indebted deepens migrant labourers' disempowerment: they work in fear of contracts being terminated before debts are cleared, which leaves them vulnerable to coercion during negotiations over work hours, food and accommodation (Chin, 2019, p. 536-537).

Furthermore, as Chen discusses, construction businesses in Singapore make extensive use of multiple levels of sub-contracting. Labour sub-sub-contractors are small operations which employ teams of migrant workers, moving them between construction sites. Economic competition forces sub-contractors to keep costs down in order to bid successfully for contracts; in turn, cost reductions impact workers' pay and leaves them vulnerable to sub-contractors imposing new contract conditions midemployment (Chin, 2019, p. 535). This is compounded by multiple conditions within contracts, including the withholding of initial salary as security deposit and deductions for food and accommodation. As their legal status is chained to the employer, workers

\footnotetext{
${ }^{9}$ Following large scale exposure of employer misconduct by NGOs after the 2008 economic recession, several reforms have been made to the Act: including that companies must pay salary monthly, and the criminalisation of kickbacks and forced repatriation of workers (Chin, 2019, p. 538-539; Ministry of Manpower, 2019).
} 
eTropic 19.2 (2020) Special Issue: Sustainable Tropical Urbanism

are reticent to complain of exploitation, abuse or injury in the fear of their contract being terminated (Chin, 2019, p. 535-536).

Subcontractors are also responsible for the accommodation of workers which implicates another social vulnerability. Construction labourers are housed in dormitories on worksites or in remote areas where they remain physically isolated from the life of the city and segregated from the Singapore community (Chin, 2019, p. 539). As Yeo notes in an interview in Film Comment:

...the dormitories for Bangladeshi workers are out in western Singapore, off the beaten track for most Singaporeans, let alone film productions. If you have no business in the industrial west of Singapore, you don't go there. These places are the underside of the city (Yeo quoted in Voelcker, 2018, n.p).

Chin argues that this isolation acts to keep migrant labourers in "social quarantine" (Chin, 2019, p. 539). Their social life depends on informal transient networks among migrant communities, including domestic workers; networks that are fragile due to high levels of labour turnover. This social segregation impacts attitudes towards migrant labourers in the Singapore imagination. Migrant workers suffer prejudice in the form of racial/ethnic/national stereotypes. ${ }^{10}$ Racial stereotyping at a state level leads to the regulation of migrants in order to protect notions of "moral hygiene" and "racial purity" (Chin, 2019, p. 540). Such prejudice is dehumanising; migrant workers treated like "masses or objects" - disposable and replaceable. Chin argues that "the state contributes to this dehumanisation when its regulations pick out the workers as potential threats to social order, bringing disease, immorality and criminality" (2019, p. 540). As a consequence of social segregation, on Sundays migrant workers gather in various 'ethnic enclaves' around the city. Such gatherings exacerbate racism as 'invisible' migrant ethnic groups become visible. ${ }^{11}$

The film, A Land Imagined, not only implicates the land, state and society in the precarity and marginalisation of construction workers, it seeks to involve the cinematic viewer as witness to the crime. In an interview by Philip Cheah for the Locarno Festival press kit, the director is asked about the choice of genres used in the film, the

\footnotetext{
${ }^{10}$ The term race is widely used in Singapore to designate ethnicity, culture and even nationality. This is seen, for instance, in the celebration of an annual 'Racial Harmony Day'.

${ }^{11}$ Little India is popular among Bangladeshi and Indian construction workers on their day off; the crowded area is avoided by Singaporeans on the same day. The riot that occurred in Little India on the 8 December 2013 was inflamed by this background involving migrant worker marginalisation and insidious racism. The investigation into the riot resulted in the jailing, caning and deportation of Indian labourers involved. It also instigated a new law prohibiting the island-wide supply and public consumption of alcohol after 10:30pm, see Liquor Control (Supply and Consumption) Act 2015, https://sso.agc.gov.sg/Act/LCSCA2015
} 
significance of cinematic forms "with elements of the investigative thriller, the police procedural, social realist drama, and a lingering sense of film noir". Yeo responds:

Like all good mysteries, the police investigative format is able to draw an audience into participation in solving the case. The film seeks to make complicit the audience in the search of Wang, by placing themselves in the environment of the migrant worker and living out his experience, in the process creating an empathetic need to understand the character and his world (A Land Imagined Press Kit, 2018, n.p.).

A Land Imagined, critiques the ethics of the Singapore Dream through exposing its land reclamation, construction sites, and migrant labour conditions. And the film implicates the audience-witness through a concluding neo-noir twist. The plot becomes increasingly difficult to follow as the main characters, the missing Chinese foreign worker Wang and the Singaporean Detective Lok, begin to morph into each other. This intersubjectivity suggests that Lok is Wang's desire to be seen; his miserable conditions and the state-sanctioned mistreatment to be observed. Furthermore, this neo-noir intersubjective twist, forces the cinema audience to view the plight of an undervalued migrant worker through the eyes of a detective, who, through the very act of investigation brings the disappearance into focus, and gives voice to the silence on workers' conditions. The film interrogates the ethics of subjugating migrant workers to a category of ghost-like "unseen and unheard noncitizens, and thus questions the morality of the Singapore Dream which requires and promotes this practice" (Peer, 2019, p. 41). In the film, the very foundations of Singapore are brought under ethical investigation - the land, state, and society.

\section{Singapore: Future Imaginary}

The film, $A$ Land Imagined, with its rhizomatic, nonlinear narrative structure where time folds upon itself and subjectivities morph, serves to remind us that the Singapore Dream for the future is intimately entwined in its long history of land reclamation as symbolic sites of the state's ability to create the city; yet the sovereign soil of Singapore is itself imaginary, dreamed through shifting sands. This link between time past and time future, and the morphing subjectivity of sand, is buried within the state's pragmatic technological imperative of land reclamation discourses and a pervasive story of survival.

\section{Singapore Dreaming}

The Singapore Dream as the guiding social imaginary of the nation-state is strongly entwined with an ideology of pragmatism based on the pursuit of 
eTropic 19.2 (2020) Special Issue: Sustainable Tropical Urbanism

economic growth as a necessity to survival. This ideology was deeply embedded within the vulnerable conditions the country faced upon full independence when it was severed from Malaysia in 1965. The new sovereign state had limited defence capabilities against neighbouring military threats, a multi-racial population which had recently experienced riots, high unemployment, extensive poverty, and a lack of natural resources including water and a hinterland.

The circumstances of independence serve to make the emphasis on pragmatism as a component of survival appear natural, rational and necessary. However, as Tan (2012) points out, the rhetoric of pragmatism is also ideological. Furthermore, pragmatism serves as justification for state decisions and actions and is tied to the notion of survival, which is upheld as the necessary condition for rational and stoical action towards economic development (Chua, 2011, p.30).

Upon independence a massive cultural transformation of the population was deemed necessary for the nascent nation-state to survive and develop economically. This economic development included land reclamation projects to make space for new industrial sites to build factories and create jobs, as well as space for state housing projects as part of a modernization scheme. The success of Singapore's economic development is thus strongly tied with these extensive land reclamation projects and, in turn, reclamation becomes an emblem of the technocratic ability of the nation-state to survive and prosper. However, land reclamation is more, it is part of the imaginary of the Singapore Dream. Land reclamation is not just a pragmatic material practice, but is culturally entwined with national identity (Jamieson, 2017, p.398). Furthermore, land reclamation, as practice and symbol, is embedded within Singapore's history.

\section{Land from Sand}

Singapore's land area has expanded by $25 \%$ over the two centuries of its modern history. The total land mass has increased from $578 \mathrm{~km}^{2}$ in 1819 to $724 \mathrm{~km}^{2}$ in 2019 (Singapore Land Authority, 2019). Established in 1819 by the colonial administrator Stamford Raffles as a British trading post, Singapore was undergoing its first land reclamation project on the south bank of the Singapore river in 1822. Through the labour of some 300 Malay, Chinese and Indian 'coolies', paid at 1 rupee a day, the wetlands area was filled in by levelling a nearby hill to provide the earth to fill the marsh and create an embankment (Abdullah, 2009, p. 165). This is now Boat Quay, and the flattened hill is Raffles Place, the centre of the financial district of contemporary Singapore, and the heart of the commercial district on Raffles' 1822 town plan (Glaser et al., 1991, p.366; Lim, 2017, p.17). The colonial reclamation projects continued; however, they appear diminutive in comparison to the projects beginning under internal self-governance (in 1959). The reclamation of mangrove swamps in Jurong 
eTropic 19.2 (2020) Special Issue: Sustainable Tropical Urbanism

which commenced in 1961, spearheaded Singapore's industrialisation plans and were followed in 1963 by a land reclamation project in Bedok as part of a series of extensive public housing projects. Land reclamation and economic development had already become strongly correlated. Upon full independence in 1965, these projects were vastly expanded as the demand for more land paralleled the urgent push for economic growth to pull Singapore out of poverty. Land reclamation became causatively associated with Singapore's post-independence rapid economic development and modernisation (Glaser et al., 1991, pp. 366-368). By the $50^{\text {th }}$ anniversary of the nationstate in 2015, Singapore had reclaimed an "astounding" $138 \mathrm{~km}^{2}$ of land (Lim, 2017, p. 19).

Landscapes of reclamation have shifted over history and continue to morph into future imaginings. During the early colonial period land fill comprised materials from hills thus contributing to the flattening of the landscape - and sand dredged from surrounding sea beds (Lim, 2017, p. 19). By the mid 1980s Singapore needed to import sand from neighbouring countries including Malaysia and Indonesia. Due to regional politics, combined with various environmental problems caused by sand extraction, Malaysia banned exports of sand to Singapore in 1997, and again in 2018; Indonesia banned sea sand exports to Singapore in 2003, and land sand exports in 2007, claiming the disappearance of some of its Riau Islands and concerns over maritime boundaries; Vietnam put a hold on dredging and exports of sand in 2009; and in the same year Cambodia announced a halt in the export of dredged river and marine sand, followed by a further ban in 2016. Singapore thus turned to other Southeast Asian countries for sand, principally Myanmar and the Philippines (Comaroff, 2014). These regional disputes demonstrate that land reclamation is never purely technological, nor are its practices isolated to the island-nation. In Jamieson's words: "Uncomfortable political, ecological, and cultural relationships become entangled in and articulated through land reclamation" (2017, p. 399).

These moving sands alert us to the fact that land reclamation is itself an imaginary. Sand is not "reclaimed" from sovereign seas, but is imported from elsewhere (Comaroff, 2014). The flow of territory itself, in the form of sand, is incorporated within cultural global flows and situated within the flexible practices of neoliberal globalisation. Sand is mined or dredged, transported and sold, by a complex network of multinational companies, agents, contractors, sub-contractors, and labourers, and is brokered by governing authorities at local and national levels. The exponential rise in the price of sand has involved it in networks of smuggling, forged export permits and the creation of 'sand mafias' (UNEP, 2019, 7-9). Singapore has legally defended its sand trading practices as properly documented; nonetheless, the details of sand sourcing is confidential and a matter of national security, as are the nation's stockpiles 
eTropic 19.2 (2020) Special Issue: Sustainable Tropical Urbanism

of sand (Comaroff, 2014). Singapore also sets environmental protection criteria for sand imports; however, responsibility for compliance is devolved to contractors.

The implications of moving sands is enormous. Sand is the second largest resource extracted and traded by volume after water. The Observatory of Economic Complexity 2018 data values sand at US $\$ 2.09$ Billion; in the same year Singapore was among the top five importers of sand in the world (Observatory of Economic Complexity, 2018). Sand extraction has recently been recognised by the UNEP as a transboundary issue and one of the major sustainability challenges of the 21 st century. Sand dredging has been identified by scientists as damaging sensitive ecosystems, accelerating coastal and river erosion, and intensifying the frequency and severity of floods and droughts (UNEP, 2019). The environmental and social impacts of sand extraction is associated with the rapid rise of cities as it is an essential element of urban infrastructure. Thus, sand is an element hidden within sustainable cities planning (UNEP, 2019).

Singapore is already moving away from sand. Due to the massive rise in the cost of sand, regional states restricting sales to Singapore, and political and environmental condemnation of Singapore's massive consumption of sand, other land reclamation technologies have been sought which bring technology and techniques from the wider world. Since 2008, Singapore, with expertise from the Netherlands, has been undertaking a project using poldering, which reduces reliance on sand (Lim, p. 19). ${ }^{12}$

Throughout its history, Singapore has been imaging, reshaping and expanding its land, and the state dreams up large future projects, using new technologies. In the early years of Singapore's independence, land reclamation was used for economic development and public housing projects. In the contemporary era, land reclamation brings direct revenue to the state. The reclamation of land is carried out by private companies that tender for construction projects; the projects create new prime locations for the city, and private developers pay premium prices for land leases on these sites. The creation of land itself has become a lucrative commodity.

The architects of territory, Uta Hassler and Milica Topalovic, recognise land reclamation as "the central paradigm of Singapore's urban development" (2014, p. 11; Jamieson, 2017, p.399). This urban development, resting on reclaimed land, holds a central place in the Singapore social imaginary and acts to enfold its citizenry within historic dreamscapes and towards future imaginings.

\footnotetext{
${ }^{12}$ Empoldering involves constructing a dike in the sea and draining the land behind it. The polder lowland area includes networks of drains, water pumping systems and canals.
} 
eTropic 19.2 (2020) Special Issue: Sustainable Tropical Urbanism

\section{Rising seas}

Land reclamation is a material symbol of Singapore's survival and prosperity, the very ground from which the Singapore Dream is created. In the early decades of Singapore's independence, survival was a daily reality. Today it remains a recurring theme, the nightmare within the dream: Singapore's existential lack; its "permanent vulnerability" (Tan, 2012, p.72; Chua, 2011, p.35). It is epitomised through the image of Singapore as a tiny island - 'the little red dot' - bereft of land, and threatened by external regional and global forces.

This leitmotif is used in the National Day Rally speeches by Prime Ministers as potent sites of ideological work to galvanise the nation. The speeches invoke national icons, including impressive land reclamation and infrastructure projects, ${ }^{13}$ to remind people of how the nation has developed - from fishing village to global city - in a matter of one generation. But the motif also acts as a mnemonic, keeping the people mindful of how these staggering accomplishments are inherently fragile (Tan, 2012, p. 70).

The Rally speech is part of National Day celebrations to commemorate Singapore's independence on the 9th August 1965. These celebrations include: exhibitions, television programs replaying the Singapore Story; music videos of patriotic songs; colourful multicultural processions; sky acrobatics by the Singapore Air Force displaying the nations' defence capabilities; singing of the National Anthem; and the climax of fireworks lighting up the global cityscape of Marina Bay. Lily Kong and Brenda Yeoh analyse this annual ritual as a 'landscape spectacle' that incites awe and "proclaims achievement". Conjured through theatrical entertainments staged against iconic sets, the celebration creates an ardent sense of nation and national identity (1997, pp. 214-216).

Within this heightened nationalistic atmosphere, the Prime Minister delivers the National Day Rally speech: pronouncing major achievements, alerting the citizenry of threats to the nations' survival, and unveiling action plans to overcome these challenges. The first Rally address was held in 1966, when the founding PM, Lee Kuan Yew, outlined the formidable difficulties faced over the first year of independence, as well as the pragmatic steps taken that demonstrated economic advancement. The speech, delivered in Malay, English and Hokkien, concluded: "Every year...we will dedicate ourselves anew to consolidate ourselves to survive; and, most important of all, to find an enduring future for what we have built and what our forebears will build

\footnotetext{
${ }^{13}$ For the 2019 Bicentenary, a glossy interactive graphic visualising the "story of Singapore's transformation, told through National Day Rally speeches" was published (The Straits Times, 2019). The graphic served to highlight Singapore's extensive and impressive infrastructure developments (which rest on reclaimed land), as a central component of the Singapore Dream.
} 
eTropic 19.2 (2020) Special Issue: Sustainable Tropical Urbanism

up" (Lee, 1966). Since the first speech the script has maintained its archetypal form a rallying call to the nation to come together to uphold the Singapore Dream, told through the Singapore Story of survival and success in the face of (ever new) external threats.

In the 2019 Bicentennial National Day Rally speech, the global environmental crisis of climate change and rising sea levels was identified as the major threat to the islandnation, and sets the scene for the PM to lay out a vision for the future, backed by plans for further land reclamation and advanced infrastructural developments. PM Lee Hsien Loong states:

We must prepare for the impact of climate change on Singapore. There are many risks and consequences. New diseases, more frequent pandemics, food shortages, forced migration of displaced populations, and even wars. Because we are a low-lying island, Singapore is especially vulnerable to one grave threat, and that is rising sea levels (Lee, 2019).

The Prime Minister alerts the nation to the need for climate change research specific to Singapore in order to understand local affects and strategize solutions. To facilitate this process, the government set up the Centre for Climate Research Singapore (CCRS). The CCRS cooperates with its counterpart research institutes in other countries to study the impact of climate change on Southeast Asia and provides scientific updates to the National Climate Change Secretariat (NCCS). The PM warns that the scientists "are finding that Singapore, being near the equator, is more vulnerable to climate change than the global model suggests" (Lee, 2019).

The National Climate Change Secretariat (NCCS) has identified the most immediate threat to Singapore as rising sea levels. About $30 \%$ of the low-lying city is less than 5 metres above sea level, hence the island-state is under threat of rising sea surges and is vulnerable to climate change effects (Temasek, 2019, pp. 10-11; NCCS). Protecting the coastline and improving drainage throughout the city is one of the governments' Climate Action Plan priorities. According the Singapore Second National Climate Change Study, produced by an international research group including the Centre for Climate Research Singapore (CCRS), the city-state is particularly vulnerable to rising sea levels because of the dynamics of melting ice sheets where reduced gravitational attraction close to ice sheets in the polar regions causes local sea level fall, while substantially increasing sea level rise farther from the ice sheets in the equatorial regions. Around the globe sea levels do not rise uniformly, and the tropical pacific region, which includes Singapore, is likely to experience the highest sea level rise from melting ice sheets; estimated at $20-30 \%$ above the global ocean average (Lundberg, 
eTropic 19.2 (2020) Special Issue: Sustainable Tropical Urbanism

2020; Marzin et al., 2015, Supp Report 3, p. 10; Temasek, 2019, p.11). As reported by the UN Intergovernmental Panel of Climate Change (IPPC) and the Singapore National Climate Change Study, tropical-equatorial circumstances further impact increasing sea levels, including through sporadic heavy rainfall, tropical storm surges and intensities of the El Niño Southern Oscillation (Lundberg, 2020; Marzin et al., 2015, Supp Report 3, p. 11; Oppenheimer et al. 2019, in IPPC, in press). Singapore's geography as a relatively low lying island near the equator, leads to a high risk of extreme flooding and presents challenges in draining surface water (NCCS; Temasek 2019, pp.12-13).

The Prime Minister's National Day Rally speech, explains how Singapore's infrastructure had previously been improved with better drainage systems and buildings constructed on platforms three metres above sea level. However, the PM warns, in the face of current knowledge these previous measures are inadequate as water can go as high as two metres above the mean sea level at high tide, thus leaving only a one metre buffer to cope with other factors, such as heavy rain. Visualising the problem for the national populace, he explains:

.... if heavy rain coincides with a high tide, the water will have nowhere to go. We will, literally, be in deep water! (Lee, 2019)

Thus, Singapore's future development for resilience and continued economic prosperity includes the construction of higher protection barriers of 5 metres at strategic positions. Furthermore, PM Lee goes on to outline extensive infrastructural ideas to protect vulnerable areas around Singapore's coastline. Indicating the lowlying area of the whole east coast from Changi Airport to the city, he envisions future lands imagined. Polders are one such vision. "Instead of just building a seawall along the coastline, you extend out with a polder, build a seawall further out, you not only protect existing low-lying areas, but you extend out and create more land reclaimed from the sea which we can use for housing and other valuable purposes" (Lee, 2019). Another vision is to reclaim islands. "We could reclaim a series of islands offshore, from Marina East all the way to Changi. We join up the islands, connect them up with barrages, and create a freshwater reservoir." Similar to the iconic Marina Reservoir (Lee, 2019). ${ }^{14}$

\footnotetext{
${ }^{14}$ Another futuristic concept, not stated in the PM's speech, is the Environmental Island "Green Float" which was unveiled at the International Built Environment Week in September 2019. Green Float is conceptualised by Shimizu Corporation, a futuristic sustainable design and construction company with an International Division Head office in Singapore. Project design specifications require a site in the Asia-Pacific on the equator to build the floating city. Singapore has been identified as a suitable site. See https://www.shimz.co.jp/en/topics/dream/content03/
} 
eTropic 19.2 (2020) Special Issue: Sustainable Tropical Urbanism

At the end of his speech, the PM, cautions:

climate change defences are existential for Singapore. These are life and death matters. Everything else must bend at the knee to safeguard the existence of our island nation (Lee, 2019).

The future of Singapore, as it faces the effects of climate change and the threat of rising sea levels, is a bold re-imagining of the land itself in order to bolster the Singapore Dream. It is technocratic and will involve more land reclamation - but now as futuristic visions involving cutting edge technologies. The use of new technologies will make these reclamation projects a first within Southeast Asia, and further distinguish Singapore as a global city - thus ensuring its survival and continued economic success. The future imagining will use less sand, and thus resolve one issue in regional politics, while simultaneously enhancing Singapore's ability to gain status as a city built on principles of sustainable development and a regional leader in the field of sustainable urbanisation.

Yet, despite this awe-inspiring imagining, the land reclamation and construction projects to create this city of the future will still rely on the labour of migrants. As Singapore takes daring technocratic actions to address climate change and sea level rise, with new projects for land reclamation and aesthetic infrastructure development, the ethical questions of migrant labourer conditions remain buried within Singapore's grand futuristic design.

\section{A Liminal Closing}

The plot summary of Yeo Siew Hua's A Land Imagined on the Internet Movie Database IMDb, briefly states:

A lonely construction worker from China goes missing at a Singapore land reclamation site, and a sleepless police investigator must put himself in the mind of the migrant to uncover the truth beneath all that sand (IMDb, 2018).

Rather than imagining "the truth beneath all that sand" as the corporeal remains of the ghostly Wang, we need to remain - as the film does - in more liminal realms. Those mountains of sand materially hold the Singapore Dream; they are the grains of sand of Singapore's vision for a resilient and expanding city; and they simultaneously reveal and hide Singapore's social and ethical values as it constructs a future land imagined. 
eTropic 19.2 (2020) Special Issue: Sustainable Tropical Urbanism

Singapore has positioned itself as willing and able to scientifically assess climate change and the risks of rising sea levels - and to gain recognition as a leader in this field within the tropical Asian region. Singapore's vision is exceedingly spectacular: spotlighting hard technological solutions, leaving 'soft' environmental-ecological aspects of coastal protection in the background, and fading out ethical questions of the construction of the futuristic Singapore Dream. While the pragmatics of Singapore's future imaginary still necessitates the neoliberal globalised flows of 'invisible', flexible and cheap migrant construction workers from around the South, East and Southeast Asian region; their corporeal labour remains buried under the sand.

However, there is another realm likewise embedded in global cultural flows - the Singapore film industry. This industry is crucial to Singapore; it forms an integral aspect of the nation's status as a global city of the arts. Furthermore, it is imperative to the state's image that Singaporean films receive international recognition and acclaim. A Land Imagined is such a film.

The film is an independent transnational co-production between Akanga Film Asia and mm2 Entertainment (Singapore), Films de Force Majeure (France), and Volya Films (The Netherlands), in association with 13 Little Pictures. It received international backing and funding, including: a New Talents Feature Grant from Singapore's Infocomm Media Development Authority; prize money from Vietnam's Autumn Meeting; the Cinémas du Monde fund from Frances' CNC; the Netherlands Film Fund and Hubert Bals Fund; as well as the Torino Film Lab Audience Lab Fund (Locarno Film Festival, Press Kit, 2018). The film received several awards prior to its premiere at the 2018 at the Locarno Film Festival in Switzerland where the film won the Golden Leopard prize. It was subsequently received acclaim at the Golden Horse Film Festival and the Singapore International Film Festival. A Land Imagined went on to be selected as the Singapore entry under the Best International Feature Film category at the 2019 Academy Awards. In 2019 it showed at the Asian Film Awards, the Hong Kong International Film Festival, and the International Film Festival Rotterdam where it continued to win awards (Yeo, 2018).

In the competitive context of transnational film production, daring films that reveal social and political issues are of particular interest to this cosmopolitan industry; they attract transnational co-production collaborators, receive international funding, are screened at film festivals, win awards and are analysed by film critics. As the Singapore film industry continues to grow, and such progressive Singaporean films achieve wider global recognition, so too will the island-state's hidden stories be revealed to international and Singaporean audiences. In turn, these cinema landscapes will impact upon the social landscape - bringing awareness of the ethical 
eTropic 19.2 (2020) Special Issue: Sustainable Tropical Urbanism

issues the state and society either buries or uncovers as it constructs its futuristic city. Through the liminal realm of filmic images, questions pertaining to social issues and human ethics are exhumed - forcing society to witness and reflect upon the land it imagines. 
eTropic 19.2 (2020) Special Issue: Sustainable Tropical Urbanism

\section{References}

Abdullah, A.K. (2009). The Hikayat Abdullah (A.H. Hill, Trans.). Kuala Lumpur: The Malaysian Branch of the Royal Asiatic Society.

A Land Imagined (6 June, 2018). A Land Imagined a film by Yeo Siew Hua. Locarno Festival Concorso internazionale (Press Kit). https://medias.unifrance.org/medias/23/243/193303/presse/les-etenduesimaginaires-dossier-de-presse-anglais.pdf

Appadurai, A. (1996). Modernity at large: Cultural dimensions of globalization. University of Minnesota Press.

Barr, M. D. (2000). Lee Kuan Yew and the "Asian Values" Debate. Asian Studies Review, 24 (3), 309-334. https://doi.org/10.1080/10357820008713278

Bullock, N. (2018). Ocularcentrism in Singapore: A Preliminary Analysis of Architecture. eTropic: electronic journal of studies in the tropics 17 (1), 25-40. https://doi.org/10.25120/etropic.17.1.2018.3640

Chaudhury, S. \& Lundberg, A. (2018). Singapore as a Creative City: Vignettes from the Perspective of la flâneuse tropique. eTropic: electronic journal of studies in the Tropics 17 (2), 110-131. http://dx.doi.org/10.25120/etropic.17.2.2018.3660

Chin, C. (2019). Precarious Work and its Complicit Network: Migrant Labour in Singapore. Journal of Contemporary Asia, 49 (4), 528-551. https://doi.org/10.1080/00472336.2019.1572209

Chua, B. H. (2011). Singapore as model: Planning innovations, knowledge experts. In A. Roy \& A. Ong (Eds.), Worlding cities: Asian experiments and the art of being global (pp. 29-54). Wiley-Blackwell.

Clarke, D.B. (Ed.) (1997). The Cinematic City. Routledge.

Comaroff, J. (2014) Built on Sand: Singapore and the New State of Risk, Harvard Design Magazine, 39. http://www.harvarddesignmagazine.org/issues/39/built-on-sandsingapore-and-the-new-state-of-risk

Deleuze, G. \& Guattari, F. (1987). A Thousand Plateaus. (Vol. 2 of Capitalism and Schizophrenia) (B. Massumi, Trans.). University of Minnesota Press. (Original work published 1980).

Department of Statistics Singapore (2019). https://www.singstat.gov.sg/modules/infographics/population

Geerlings, L.R.C. \& Lundberg, A. (2018). Global discourses and power/knowledge: theoretical reflections on futures of higher education during the rise of Asia. Asia Pacific Journal of Education, 38, (2), 229-240. https://doi.org/10.1080/02188791.2018.1460259

Glaser, R., Haberzettl, P. \& Walsh, R.P.D. (1991). Land reclamation in Singapore, Hong Kong and Macau. GeoJournal 24, 365-373. https://doi.org/10.1007/BF00578258

Gray, G. (2010). Cinema: A Visual Anthropology. Berg.

Greene, W. (March 22, 2019). Review: A Land Imagined Is a Noir-Tinged Rumination on Identity. Slant. https://www.slantmagazine.com/film/review-a-land-imagined-is-a-noirtinged-rumination-on-identity/

Hassler, U. \& Topalovic, M. (Eds) (2014). Constructed land: Singapore 1924-2012. Singapore: ETH Zurich DArch and Future Cities Laboratory.

IMDb (2018). A Land Imagined, Plot Summary. https://www.imdb.com/title/tt8726116/?ref =tt sims tti

Jamieson, W. (2017). There's Sand in My Infinity Pool: Land Reclamation and the Rewriting of Singapore. GeoHumanities, 3 (2), 396-413.

https://doi.org/10.1080/2373566X.2017.1279021 
eTropic 19.2 (2020) Special Issue: Sustainable Tropical Urbanism

Kong, L. \& Yeoh, B.S.A. (1997). The construction of national identity through the production of ritual and spectacle. Political Geography 16 (3), 213-239.

https://doi.org/10.1016/0962-6298(95)00135-2

Law, L., Wee, C. W-L., \& McMullan, F. (2011). Screening Singapore: The Cinematic Landscape of Eric Khoo's Be With Me. Geographical Research, 49(4), 363-374. https://doi.org/10.1111/j.1745-5871.2011.00717.x

Lee, H.L. (2019). National Day Rally Speech. 18 August. Prime Minister's Office Singapore https://www.pmo.gov.sg/Newsroom/National-Day-Rally-2019

Lee K.Y. (1966) National Day Rally Address by Singapore's Prime Minister, National Theatre, Singapore, 8 August. National Archives Singapore. Audiovisual file. https://www.nas.gov.sg/archivesonline/audiovisual records/record-details/68691f571164-11e3-83d5-0050568939ad

Liew, K. K., \& Teo, S. K. (2017). Singapore Cinema: New Perspectives. Routledge. https://doi.org/10.4324/9781315683874

Lim, E. (2018). Celluloid Singapore: Cinema, Performance and the National. Edinburgh University Press. https://doi.org/10.3366/edinburgh/9781474402880.001.0001

Lim, T.S. (2017). Land from Sand: Singapore's Reclamation Story. BiblioAsia 13 (1), 16-23.

Lundberg, A. (2016). Rhizomes, Weak Links and Far Flung Networks: Empowering women's space in Tropical Asia. eTropic: electronic journal of studies in the tropics, 15 (2), 106-117. https://doi.org/10.25120/etropic.15.2.2016.3547

Lundberg, A. (2020). Balinese Dancer wearing a Gas Mask: Climate Change and the Tropical Imaginary. [COP26 Perspectives Special Issue]. Scottish Geographical Journal RSGJ. 136 (1-4). https://doi.org/10.1080/14702541.2020.1858589

Marzin, C., Rahmat, R., Bernie, D., Bricheno, L., Buonomo, E., Calvert, D., Cannaby, H., Chan, S., Chattopadhyay, M., Cheong, W-K., Hassim, M.E., Gohar, L., Golding, N., Gordon, C., Gregory, J., Hein, D., Hines, A., Howard, T., Janes, T., ...Zhang, S. (2015). Singapore's Second National Climate Change Study - Phase 1. Published by Met Office, Exeter, UK; Centre for Climate Research Singapore, Singapore; National Oceanography Centre, Liverpool, UK; CSIRO, Australia; Newcastle University, UK http://ccrs. weather.gov.sg/publications-second-National-Climate-Change-StudyScience-Reports

Ministry of Foreign Affairs Singapore (MFA). https://www.mfa.gov.sg/SINGAPORESFOREIGN-POLICY/International-Issues/Climate-Change

Ministry of Manpower (MOM) (December, 2019). https://www.mom.gov.sg/

Ministry of the Environment and Water Resources; Ministry of National Development (2016) Singapore's Climate Action Plan: A Climate-Resilient Singapore, For a Sustainable Future. https://www.nccs.gov.sg/docs/default-source/publications/a-climate-resilientsingapore-for-a-sustainable-future.pdf?sfvrsn=662eccb 12

National Climate Change Secretariat (NCCS). Impact of Climate Change on Singapore. https://www.nccs.gov.sg/singapores-climate-action/impact-of-climate-change-insingapore/

Observatory of International Complexity (2018). https://oec.world/en/profile/hs92/52505/

Ong, A. (2011). Introduction Worlding Cities, or the Art of Being Global. In Roy, A. \& Ong, A. (Eds.). Worlding Cities: Asian Experiments at the Art of Being Global (pp. 1-28). Wiley-Blackwell.

Oppenheimer, M., Glavovic, B. C., Hinkel, J., van de Wal, R., Magnan, A.K., Abd-Elgawad, A., Cai, R., Cifuentes-Jara, M., DeConto, R.M., Ghosh, T., Hay, J., Isla, F., Marzeion, B., Meyssignac, B. \& Sebesvari, Z. (2019). Sea Level Rise and Implications for LowLying Islands, Coasts and Communities. In H.-O. Pörtner, D.C. Roberts, V. MassonDelmotte, P. Zhai, M. Tignor, E. Poloczanska, K. Mintenbeck, A. Alegría, M. Nicolai, A. Okem, J. Petzold, B. Rama, N.M. Weyer (Eds.). IPCC Special Report on the Ocean and Cryosphere in a Changing Climate, In press. 
eTropic 19.2 (2020) Special Issue: Sustainable Tropical Urbanism

Patapan, H. (2013). Modern Philosopher Kings: Lee Kuan Yew and the Limits of Confucian 'Idealistic' Leadership. European Journal of East Asian Studies, 12 (2), 217-241. https://doi.org/10.1163/15700615-13120204

Peer, J.T. (2019). Hidden Transcripts in Singaporean Film: An Anthropological Analysis. [Unpublished Honours Thesis]. James Cook University, Australia.

Sassen, S. (2002). The Global City: New York, London, and Tokyo (2nd Ed.). Princeton University Press. First published 1991. https://doi.org/10.1515/9781400847488

Shiel, M. \& Fitzmaurice, T. (Eds) (2001). Cinema and the City: Film and Urban Society in the Global Context. Blackwell. https://doi.org/10.1002/9780470712948

Sim, J. (2020). A Land Imagined: Transsensorial States of Transmigration. International Journal of Diaspora \& Cultural Criticism. 10 (1), 31-61. https://doi.org/10.15519/dcc.2020.01.10.1.31

Singapore Land Authority. (2019). Total Land Area of Singapore (data set). https://data.gov.sg/dataset/total-land-area-of-singapore

Tan, K.P. (2012). The Ideology of Pragmatism: Neo-liberal Globalisation and Political Authoritarianism in Singapore. Journal of Contemporary Asia, 42 (1), 6792. https://doi.org/10.1080/00472336.2012.634644

Temasek (January 2019). Climate Change and Rising Sea Levels: Mitigating and Adapting to the Looming Threats. Prepared by AlphaBeta strategyxeconomics.

The Straits Times. (2019, Aug 18). Greater Southern Waterfront \& key projects that have shaped Singapore. The Straits Times.

https://graphics.straitstimes.com/STI/STIMEDIA/Interactives/2019/08/ndr-2019transform-sg/index.html

UNEP (2019). Sand and sustainability: Finding new solutions for environmental governance of global sand resources. GRID-Geneva, United Nations Environment Programme, Geneva, Switzerland. https://unepgrid.ch/en

Voelcker, B. (August 23, 2018). Interview: Yeo Siew Hua. Film Comment. Published by Film at Lincoln Centre. https://www.filmcomment.com/blog/locarno-interview-yeo-siewhual

Yeo S. H. (Director). (2018). A Land Imagined [Film]. Akanga Film Asia, Films de Force Majeure, mm2 Entertainment \& Volya Films. 
eTropic 19.2 (2020) Special Issue: Sustainable Tropical Urbanism

\section{Acknowledgements}

The authors acknowledge with gratitude the three anonymous reviewers for their thorough reading and critical appraisal of earlier drafts of this paper. The reviewers' comments have been valuable in helping to reshape and improve the manuscript.

Associate Professor Anita Lundberg is a cultural anthropologist. Her ethnographies have explored everyday urban life, the cinematic city, and neoliberal higher education in Singapore; climate change street art in Bali; the architecture of a Malay house and garden of indigenous trees; and a whale hunting village in Indonesia. Anita has won awards and held international fellowships: LIA TransOceanik (CNRS, JCU, Collége de France); The Cairns Institute (TCl); Evans Fellow, Cambridge University, UK; Guest Researcher, Maison Asie-Pacifique, Université de Provence, France; Visiting Fellow, Institute of the Malay World and Civilization, National University Malaysia; and Anthropologist-in-Residence, Rimbun Dahan, Malaysia. She has curated exhibitions in NY, LA, Paris and Sydney, and her own research has been exhibited at the Australian National Maritime Museum, the National Art Gallery of Malaysia and Alliance de Française. Anita was a Post-Doctoral Fellow, Cambridge University, UK, she has a PhD in Anthropology, and an MA in Science \& Technology Studies.

Jasmin Thamima Peer is currently a Learning Advisor at James Cook University's Indigenous Education and Research Centre, and a Research Assistant at LocuSAR, a social research consultancy that provides expert analysis and professional education across Australia and the Asia-Pacific. Jasmin, originally from Singapore, is currently based in Cairns, Australia. Her research interests revolve around the anthropology of urban spaces, art, and language. She graduated in 2020 from James Cook University with a BA (Honours First Class) with a major in Anthropology and a minor in Literature. Her honours thesis was titled "Hidden Transcripts in Singaporean Film - An Anthropological Analysis". 